\title{
The Psychology of Place Attachment and Psalm 128
}

\author{
HENDRIK VIVIERS (UNIVERSITY OF JOHANNESBURG)
}

\begin{abstract}
The Psychology of Place Attachment confirms the cognitive-emotional bond that humans, since early times, have with a specific place. A material place is not only shaped physically and psychologically/spiritually by its inhabitants, but it in turn also shapes them, as it mediates the meanings ascribed to it through its sensuous presence. Appreciating Ps 128 through the "readerly lens" of place attachment (also as part of the ma "alôt-collection and Psalter as a whole), it was found that the poet(s) of this wisdom (-Torah ethical) psalm intuitively grasped the psychological benefits that a place exerts on its inhabitants. The experiences of memory, belonging, positive emotions, privacy and reflection, comfort and security, entertainment and aesthetics are reflected in the psalm. Both the small, intimate household and larger community Zion/Jerusalem, mediate Yahweh's presence and blessing, also as a retributive response to a wise life-style. Zion/Jerusalem and all it encompasses, become the centre of the universe, the place par excellence for a fulfilled life.
\end{abstract}

KEYWORDS: Psalm 128, ma ${ }^{\text {‘a }}$ ôt-collection (Pss 120-134), wisdom, place attachment, psychological benefits, materiality, space, Zion.

\section{A INTRODUCTION}

In a recent newspaper column, the psychologist Wilhelm Jordaan ${ }^{2}$ referred interestingly to the "territorial imperative," the urge to occupy and defend (sometimes at all costs) a chosen territory. This is something that humans and animals share alike and has to do with access to resources to improve chances of survival. If there is more to this than just survival in the case of animals, we do not really know, whether they perhaps have some higher ideal to live up to? Animals do not have the language to tell us this, while humans as rational, symbolizing beings have language to express verbally or in writing (e.g. texts)

* Article Submitted: 2019/03/04; peer reviewed: 2019/05/17; accepted: 2019/07/18. Hendrik Viviers, "The Psychology of Place Attachment and Psalm 128," OTE 32 no. 2 (2019): 426-443. DOI: https://doi.org/10.17159/2312-3621/2019/v32n2a10

1 Dedicated to Prof Phil J. Botha, a colleague and friend for almost four decades. Over the years he not only impressed with his humanness, but in his academic work notably practised what our "Doktorvater," the late Prof Willem S. Prinsloo has taught his students, to "keep your finger on the text."

2 Wilhelm Jordaan, "Ruimtekapers, dít is nié goeie maniere nie," Beeld (13 Februarie 2019): 10, referring to the author Robert Ardrey who created the term "territorial imperative." 
what fulfilment they experience by bonding with a particular place. It has become clear that "place" is not simply a case of lifeless matter, but indeed that matter/materiality "matters" very much. Material "things" like a house or farm or piece of nature, might not have intrinsic meanings, but they soon beget these as we confer our cultural-ideological values onto them. In this process they become "animated," even beget some "agency" to mediate some of our beliefs. This has been aptly recognized lately by the so-called material turn in the study of religion of which Meyer ${ }^{3}$ has the following to say: "It is a generating process in which subjects and objects are mutually constituted, becoming enmeshed and indistinguishable from one another, and which also creates surplus or excess. Humans both shape and are shaped by the material world in such dynamics...generating a sense of something divine, ghostly, sublime, or transcendent." It is clear that a special "place" as part of the material world, is more than just a place but something with a sensuous presence, the lastmentioned to be illustrated with the appropriate insights of place attachment theory (see below). And it is a confirmation that our humanness is as much anchored in materiality as in spirituality.

When reading texts one often overlooks other (non-human) elements as part of the text, because our interests are usually anthropocentric, mostly focused on what human characters do and experience. A brief glance at Ps 128 indicates that the motif "place" is conspicuously present in it: "home," "table," "Zion," "Jerusalem" and "Israel" and similarly also in its immediate literary context, the ma "alot-collection (Pss 120-134). "Place" is not merely the scenery or background but co-constitutive in creating meaning. This has been aptly noticed by Prinsloo ${ }^{4}$ with his spatial study on the šîrê hamma 'alôt. Informed by the theorists Lefebvre and Soja, he distinguishes between first space (physical/concrete space), second space (imagined space or the emotive meaning of space) and third space (lived space, where different ideological groups vie for power), where each one is in a real sense also the other. To be off-centre implies negative space, and to be at-centre, positive space. In the $m a^{\text {'a }}$ lot-collection, Zion/Jerusalem becomes the at-centre space par excellence. He also prefers to use "space" instead of "place," because of the emotional connotation that the first-mentioned has. Whereas Prinsloo's study focuses on narrated (literary) space, ${ }^{5}$ contributing inter alia to the poetic artistry of these psalms, this contribution uses the psychological theory of place attachment as a "lens" to appreciate Ps 128. There is overlap (e.g. an enriched understanding of the

3 Birgit Meyer, "An Author meets her Critics: Around Birgit Meyer's 'Mediation and the Genesis of Presence: Toward a Material Approach to Religion."” Religion and Society: Advances in Research 5 (2014): 205-254. See also David Chidester, Religion: Material Dynamics (Oakland, CA: University of California Press, 2018), 30, 34, 36.

4 Gert T. M. Prinsloo, "The Role of Space in the שירי המעלות (Psalms 120-134)," Bib. 86 (2005): 460.

5 Prinsloo, "The Role of Space," 459 n 13. 
emotional texture of the text) but this reading is decidedly "readerly," ${ }^{\circ}$ mostly appreciating the "resonance/rapport" between a modern reader and an ancient text. The last-mentioned stays topical, relevant and worth reading as we satisfyingly rediscover our shared humanity, experiencing something of our own "bonds with places" in the musings of the ancients.

In what follows, the theory of the psychology of place attachment will be summarily presented and then an application of this theory to Ps 128, a reading of it specifically through this "lens," will be done.

\section{B THE PSYCHOLOGY OF PLACE ATTACHMENT}

"Place attachment, the cognitive-emotional bond to a meaningful setting...is a common phenomenon that has been observed across cultures, place types and eras," say Scannel and Gifford. ${ }^{7}$ It is therefore understandable that it has been studied incisively not only by the social sciences but also by architects, town and landscape developers/planners, engineers, and so on. Place attachment theories have proliferated especially over the last three to four decades. In an effort to structure the vast amount of psychological literature that has appeared, Scannel and Gifford ${ }^{8}$ have developed a multidimensional model to explain how place attachment is realized. They refer to it as the person-place-process framework where "person" indicates who is attached (moulded by individual-/collectivebased meanings), "place" indicates to what is the attachment (both social and physical qualities of place) and "process" refers to the psychological process how attachment is realized and expressed (through affect, cognition and behaviour). A few comments on each of these indicators will suffice.

"Person"9 refers first to the individual who holds a place dear because of fond memories, positive emotional experiences and cultural meanings of a specific place that have become internalized. Many personal factors ${ }^{10}$ can play a

\footnotetext{
6 The SBL's Psychological Hermeneutics subgroup formulates this kind of reading succinctly: "Psychological Criticism complements approaches that consider the texts and their impact/s from the perspective of the reader, alongside literary, rhetorical and theological approaches, identifying how texts operate within the minds of their readers, or portray thoughts and motivations of the characters in their narratives" (https://www.sbl-site.org/meetings/Congresses_ProgramUnits.aspx?MeetingId=34)

7 Leila Scannel and Robert Gifford, "The Experienced Psychological Benefits of Place Attachment," JEP 51 (2017): 256. See also Maria Lewicka, "Place Attachment: How Far have we come in the last 40 years?" JEP 31 (2011): 209.

8 Scannel and Gifford, "The Experienced Psychological Benefits," 257; Leila Scannel and Robert Gifford, "The Psychology of Place Attachment," in Environmental Psychology (5 ${ }^{\text {th }}$ ed.; ed. R. Gifford; Colville, WA: Optimal Books, 2013), 274-276.

9 According to Lewicka, "Place Attachment," 222-227, previous research has focused mostly on this dimension and neglected "place" and "process."

10 Scannel and Gifford, "The Psychology," 278-280.
} 
role that strengthen the bond with a place, for example: much time spent in a favourite place continuing the ancestral lineage (e.g. family farm) can lead to a stronger attachment than only a brief visit by a tourist; "congruence," 11 the fit or resonance of a specific place for a specific purpose that complies with needs of the self, can lead to an instantaneous bond (e.g. nature experience) other than much time spent there; mobility or extensive travelling even for long periods of time, do not severe ties with a place, and people upkeep these ties with "homesickness;" ownership of places can be a positive factor, although "renters" can have similar strong bonds with a place; gender, where women tend to bond stronger to a place because of social reasons while men choose places for activities, and females usually place a stronger emphasis on memory than males, ${ }^{12}$ development, namely age differences can influence attachment, for instance, parents with children needing others and likewise the aged their peers, but also places that enhance their memories and self-reflection. Age, however, does not differ in the kinds of psychological benefits (see below) experienced. ${ }^{13}$ "Person" refers secondly to culture and ethnic factors, collective meanings about place that groups or communities embrace, and which determine the bond they have with a particular place. These include genealogy, links through family lineage or ethnic association where places, for instance, carry family names. One of the theories distinguishable from place attachment but incorporated by Scannel and Gifford under collective ownership is "Place Identity." Here the "borders" between the self and place become fluid and "who we are including where we are,"14 enhancing self-esteem, distinctiveness and identity. Cosmological meanings that groups confer on places obviously elevate their esteem, experienced by "...their natives as the center of the universe." 15 These meanings usually lead to pilgrimages to these "centres," for instance religious Jews to Jerusalem/Israel and Muslims to Mecca. Pilgrimages can also be secular, for instance sports fanatics regularly visiting their favourite sports venues (e.g. the annual Wimbledon tennis tournament), similarly to be "uplifted" whilst in

11 Scannel and Gifford, "The Psychology," 275, also refer to this as "functional attachment" emphasizing "place dependence," and even though differentiated by some scholars, it is closely related to place attachment. "Congruence" matches the notion of "compatibility" that is emphasized in Attention Restoration Theory; for the lastmentioned see Stephen Kaplan, "The Restorative Benefits of Nature: Toward an Integrative Framework," JEP 15 (1995): 169-182.

12 Scannel and Gifford, "The Experienced Psychological Benefits," 262.

13 Scannel and Gifford, "The Experienced Psychological Benefits," 263.

14 Scannel and Gifford, "The Psychology," 275. See also Herman Holtzhausen, "Ubuntu, Mysticism and Land Reform: A Spiritual Response to the Debate on the Expropriation of Land without Compensation" (unpublished summary article of $\mathrm{PhD}$, University of Pretoria, 2019): 16, 18, who, whilst promoting a spirituality of "Ubuntu" as an ethical guideline for land reform, makes insightful remarks on farmers' identity with land, as people who are the land walking.

15 Scannel and Gifford, "The Psychology," 283. 
these very special environments. The last-mentioned often beget (ascribed) "agency" as people "animate" these places with endowed meanings ${ }^{16}$ even to the extent of having a "spell" over them (e.g. "holy ground"). Places become "sacred," both religiously and profane, through age-old and continuous "interpretation" (e.g. a mountain as the abode of a god) and "ritualization" (e.g. offerings to both place/god, where the borders blur, and claiming ownership of these abodes), whilst mediating ultimate meaning from a "world beyond." 17

The second in the tripartite framework, "place," refers first to social features that a place provides to forge social ties of different kinds. Human beings are social persons and cannot live without social interactions with others (family, friends, neighbours, fellow inhabitants of a town/province/country). ${ }^{18}$ Regular social interactions lead to social capital, advantages such as practical (e.g. tool sharing), informational (e.g. strategic information on resources), safety (e.g. extra pair of eyes to watch your house when away) and emotional support (e.g. empathy after a great loss). Homogeneity but also diversity of communities make them attractive. "On the flip side, social disorder is destructive to place attachment." "Place" secondly refers to a setting's physicality, its geographical scale (types of places) and also aesthetic and landscape features. The lastmentioned is self-explanatory where a beautiful view or scenery naturally attracts, and not only for its beauty but also signalling the presence of resources needed for survival that humans discovered in their evolutionary history. ${ }^{20}$ Scannel and Gifford identify six types of spaces ${ }^{21}$ and some accompanying benefits of well-being, namely a manipulable object space (e.g. favourite chair or hammock, although attachment seems to happen in places larger than the

16 People are attached to the "meanings" they project on places, which in themselves are devoid of intrinsic meanings: “...the meaning of place is an intermediate link between the place's physical properties and strength of emotional bonds with it (place attachment). In order to understand attachment, one must first identify its meaning" says Lewicka, "Place Attachment," 221; see also Scannel and Gifford, "The Psychology," 291. These authors acknowledge especially Richard Stedman, "Is it Really just a Social Construction? The Contribution of the Physical Environment to Sense of Place," Society and Natural Resources 16 (2003): 671-685, who, however, apart from its social meanings, also emphasize the contributing role of the physical properties of place in this meaning-bestowing exercise.

17 Chidester, Religion: Material Dynamics, 30, 34, 36.

18 Scannel and Gifford, "The Experienced Psychological Benefits," 256, refer to the classic study of Marc Frier who studied a West End Boston neighbourhood, which had to be restored because of dilapidation. The restoration completely changed its original character and some inhabitants even had to leave. They went into "mourning" as if they have lost loved ones.

19 Scannel and Gifford, "The Psychology," 281.

20 Scannel and Gifford, "The Psychology," 289.

21 Scannel and Gifford, "The Experienced Psychological Benefits," 258, following Freundschuh and Egenhofer's taxonomy of "scale." 
body); a non-manipulable object space (e.g. room, office - privacy, personal growth, freedom), environmental space implying locomotion and route knowledge/mental map (e.g. house, neighbourhood, ${ }^{22}$ park - positive emotions, comfort, safety, entertainment and connectedness to nature), geographic space that cannot be fully perceived through locomotion (e.g. large cities, regions, countries - belonging, memory), panoramic space (viewed from a single vantage point - not much attachment due to lack of locomotion) and map space (e.g. large space presented as symbols - no attachment). Scannel and Gifford ${ }^{23}$ make a few more interesting comments on physical space: people are more "rooted" in single family dwellings than in multi-unit facilities; cul-de-sac areas in neighbourhoods increase attachment as well as new urban developments that encourage "walking;" community size is less important than its social ties.

"Process," the third focus of Scannel and Gifford's multidimensional framework, has to do with the psychological process of how attachment becomes realized and expressed. "Cognition" plays a role that includes knowledge (mental representations), memories and beliefs that provide meaning about place. "Emotions" obviously strengthen the bond with a particular place and (positive) "behaviour" usually signifies this bond. Expanding on their 2010 study, ${ }^{24}$ Scannel and Gifford ${ }^{25}$ identified thirteen psychological benefits that "place bonded" people experience, encapsulating cognition, emotions and behaviour. They are the following (from the most to the less commonly experienced, and expressed in percentages in brackets): memories (69\%) - place attachment supports and evokes memories, connecting people (often vividly) to the recent past or even early, ancestral history; belonging (54\%) - a sense of "at homeness," rootedness/origin and interpersonal/social ties; relaxation (49\%) - restoration of depleted attentional (mental) fatigue, as well as recovery from emotional and physiological stress; ${ }^{26}$ positive emotions $(38 \%)$ - happiness, joy, hope and pride are experienced, of which happiness was the most frequently reported. An important emotion not mentioned is that of "awe/wonderment," which is often present at special places (e.g. nature). Scannel and Gifford note that $5 \%$ of people reported negative emotions of some places, associated with painful memories; activity support (33\%) - implies a goal-supportive benefit like work (for a living), hobbies and interests; comfort and security (31\%) - physical comfort (food, nourishment, climate) and physical safety (e.g. sanctuary, safe haven); personal growth (22\%) - insight, self-reflection; freedom (19\%) - freedom,

22 Neigbourhoods have been mostly researched in attachment theories according to Lewicka, "Place Attachment," 211.

23 Scannel and Gifford, "The Psychology," 282.

24 Leila Scannel and Robert Gifford, "Defining Place Attachment: A Tripartite Organizing Framework," JEP 30 (2010): 1-10.

25 Scannel and Gifford, "The Experienced Psychological Benefits," 259-262; see also Lewicka, "Place Attachment," 226.

26 Kaplan, "The Restorative Benefits of Nature," 169-182. 
control and autonomy to make own decisions (at "your" particular place); entertainment (19\%) - a place that provides novelty, activity, interest and excitement; connection to nature (11.5\%) - a "wilderness" experience, confirming the self/identity and enhancing relaxation; practical benefits $(9 \%)-$ practical needs and amenities to fulfil these (food, services); privacy (7\%) solitude, seclusion, "peace and quiet;" aesthetics $(7 \%)$ - beautiful view, scenery, visual character of a particular place evoking pleasure. Apart from these thirteen benefits, Scannel and Gifford ${ }^{27}$ also note that a small minority of people do not have any attraction to a place, arguing that it is people that matter and not a specific place.

Behaviour (positive), unlike cognition and emotion that are clear in the mentioned thirteen benefits, does not feature conspicuously but is implied. If someone has a deep affection for a place, s/he will certainly be moved to care for it. Scannel and Gifford ${ }^{28}$ describe this caring attitude as "stewardship" and it is noticeable especially in those with a pro-environmental attitude. In an insightful study on American farmers, using "attachment theory of security and exploration" (á la John Bowlby, Mary S. Ainsworth) to expand the psychological process just explained, Quin and Halfacre ${ }^{29}$ found that a farm acts as a "caretaker," providing security and exploration possibilities to the ("infant") farmer. Roles also switch where the farmer becomes the "caretaker" (almost as being "called") and the farm the "infant" to be looked after and "wrap your arms around it..." 30

With this brief explication of what place attachment comprises, it is time to take a closer look at Ps 128 and determine if some of these modern insights are reflected in this ancient poem. And also confirming our shared human need for a "place," ever since the early times of humankind.

\section{PLACE ATTACHMENT AND PSALM 128}

"Person" in the ancient Near Eastern world is different from our modern (Western) individually based cultures, namely communally based, where the individual was fully embedded in the community. Ignoring the latter would be social death. "Place," as indicated above and important for this contribution, is co-constitutive of a people's identity ("rootedness") both in its sociality and physicality. Focusing first on the two notions "person" and "place" in regard to Ps 128 's broader context, the cognitive, emotive and behavioural "psychological process" of attachment will be attended to when focusing specifically on Ps 128.

27 Scannel and Gifford, "The Experienced Psychological Benefits," 262.

28 Scannel and Gifford, "The Psychology," 285.

29 Courtney E. Quin and Angela C. Halfacre,"Place Matters: An Investigation of Farmers' Attachment to Their Land," Human Ecology Review 20 (2014): 123-124, 127. 30 Quin and Halfacre, "Place Matters," 117, adds: “... and provide...environmental security to their land." 
The generating context over time and place of Ps 128, part of the coherent šî $\hat{e}$ hamma 'a ôt collection (Ps 120 134), ${ }^{31}$ forming part of Book V (Pss 107-150) and in turn of the whole of the Psalter, is therefore important to grasp to get a glimpse of who wrote all of this, from where and when, and with what intentions (authors, editors, final redactors). The "creators" (equals "Person") with all their ideologies/theologies and accompanying values shaped by their situations in time and in/through place, and encoding these in their texts, are important especially for these collective cultural and ethnic meanings of which they are the carriers. ${ }^{32}$ Psalm 128 is therefore not a lone-standing piece of poetry but part and parcel of the long historical growth and final literary profile of the Psalter. Its immediate context, the šîrê hamma 'a lôt collection, with its individual psalms and smaller collections with many Sitze im Leben (spanning the whole history of Israel), ${ }^{33}$ obtained a Sitz in der Literatur as part of Book V, in the post-exilic, Persian-Hellenistic times. ${ }^{34}$ This incorporation into Book V between Ps 118 and the antiphonal Ps 136 ("Give thanks to the Lord...") was probably due to liturgical reasons. ${ }^{35}$ Human supports this liturgical orientation ${ }^{36}$ and use of Book $\mathrm{V}$ at "...the annual festivals Pešah (113-118), Šabūot (119) and Sūkkot (120-134)." He, however, indicates the post-cultic character of Book V and the šîrê hamma "alot, by describing them as fulfilling a "meditative pilgrimage",37

31 Hendrik Viviers, "The Coherence of the ma "a lôt Psalms (Pss 120-134)," ZAW 106 (1994): 275-289.

32 Commenting on "third space" or the vying for power by opposing (ideological) groups, Prinsloo, "The Role of Space," 474-477, argues that at the beginning of the $4^{\text {th }}$ century BCE, a group of displaced Levites were trying to recover their former positions that they have lost under the post-exilic temple aristocracy. It is their "voice" that is heard in the ma "alot-collection. Christoph Levin, "The Edition of the Psalms of Ascents," in Centres and Peripheries in the Early Second Temple Period, ed. Ehud Ben Zvi and Christoph Levin (Tübingen: Mohr Siebeck, 2016), 381-382, 399-400, however, argues that the collection is all about motivating post-exilic Jews to return to Zion/Jerusalem from the diaspora.

33 Levin, "The Edition of the Psalms of Ascents," 391-397, provides a view of socalled nuclei (and possible Sitze) of some psalms (120; 121; 122; 123; 124; 128; 129; $131 ; 133 ; 134)$ that were expanded with later editorial additions.

34 Dirk J. Human, “'From Exile to Zion' - Ethical Perspectives from the Twin Psalms 127 and 128," OTE 22 (2009): 69.

35 E.g. Ps 118:1-2, "Give thanks to the Lord...Let Israel say..."; the latter words were added to Pss 124:1 and 129:1 to imitate 118:1-2; so also the wish "Peace be upon Israel..." with which Pss 125 and 128 close and present elsewhere, argues Levin, "The Edition of the Psalms of Ascents," 385-386, 388.

36 Book $\mathrm{V}$ is also hymnic, with an emphasis on David and a universal awareness, according to Human, "From Exile to Zion," 67.

37 Human, "From Exile to Zion," 67-69, follows Zenger in regarding Book V as postcultic and on the ma ${ }^{a} l o \hat{t}$-collection itself says (68): "As a later postscript to this collection, Ps 137 sets the context of the exile on which the Sîre Hamma a alôt are directed. With the focus on the Israelite history the pilgrimage of Israel's second exodus 
through Israelite history, to create restoration and eschatological and Messianic hope (see e.g. Ps 132). ${ }^{38}$ This happened at a time when real pilgrimages might not have been possible for many. Human's labelling of Pss 120-134, "From Exile to Zion," refers to the Babylonian exile. Levin, ${ }^{39}$ however, expands this to include the return of more "exiles" than only those from the Babylonian one, namely the return to Zion of those in the entire diaspora. The later redactional heading to the Psalms of Ascents, the plural $m a^{a}$ alôt is indicative of this. Furthermore, Levin ${ }^{40}$ offers a novel and acceptable hypothesis that this "pilgrimage" to Zion/Jerusalem is a one-way, single journey. This is the (ultimate) "place" to be, "for now and evermore" (Pss 121:8; 131:3).

What makes Zion/Jerusalem ideological-culturally so special, of which the "household" of Ps 128 forms part? Prinsloo ${ }^{41}$ encapsulates succinctly: "The poem (Ps 134) stands in stark contrast to the complete negative tone of Ps 120. Space has been recreated through the physical experience of ascending to Jerusalem and the emotional experience of ascending to YHWH from negative to positive space, from off-centre to at-centre...A real pilgrimage to Jerusalem and the temple became a spiritual pilgrimage from שמים tow an ascent into the arms of YHWH." As for many religious groups bestowing cosmological meaning on their special places, Zion/Jerusalem has become the centre of the universe. It is the sacred, chosen seat of their deity whose presence is mediated whilst being there (Ps 132:13-14). Levin ${ }^{42}$ says: "Zion is the place of blessing per se (133:3). From there, Yahweh disseminates his blessing (128:5; 134:3)." And likewise also Allen: ${ }^{43}$ "Zion is Yahweh's powerhouse...Zion is a doorway that opens out into the power behind the world." This is indeed "Zion-SegenTheologie" as Seybold ${ }^{44}$ has said many years ago. And this is what needs to be contemplated/meditated on in the ma alôt-collection, as devotees move through its different "stations," creating hope and confidence also for the future. Prinsloo ${ }^{45}$ shows the movement from negative space to positive space through the collection's five triads, telling its "story": Pss 120-122: from "exile" to

starts at the Egyptian exodus (113-118), sojourns at Sinai for the Torah (119) and arrives at Zion (120-134), where Yahweh is hailed as world ruler (135-136). Yahweh's deeds and covenant promises throughout Israelite history thus function to revive hope for the future in distressful and dangerous post-exilic contexts;" see also Johannes P.M. van der Ploeg, Psalmen, deel 1. BOT 7B (Roermond: J J Romen, 1974), 347, who refers to the $m a$ 'alot $t$-psalms as "devotie boekje."

38 Also Prinsloo, "The Role of Space," 475-476.

39 Levin, "The Edition of the Psalms of Ascents," 383.

40 Levin, "The Edition of the Psalms of Ascents," 382.

41 Prinsloo, "The Role of Space," 472-473.

42 Levin, "The Edition of the Psalms of Ascents," 399.

43 Leslie C. Allen, Psalms 101-150, (WBC 21; Waco, TX: Word, 1983), 218.

44 Klaus Seybold, "Die Redaktion der Wallfahrtspsalmen," ZAW 91 (1979): 268.

45 Prinsloo, "The Role of Space," 465, 467, 469, 470, 472. 
journey to the joyous arrival in Jerusalem amongst companions and in Yahweh's presence; Pss 123-125: looking up to Yahweh (in the temple), ${ }^{46}$ looking back to being saved from Sheol, and being embraced/safe with Yahweh as the mountains enclose Jerusalem; Pss 126-128: the daily labour of sowing and harvesting, building a house and family and enjoying the fruits of labour, family and community; Pss 129-131: recalling oppression, the "depths" to be saved from, consolation and intimate, infant-like security; Pss 132-134: Yahweh's and ("David's") dwelling, community harmony which Yahweh richly blesses, and final praise and blessing, summarizing the whole collection. ${ }^{47}$ These deep-seated cultural meanings to which the Israelites/Jews became attached to, make Zion/Jerusalem ${ }^{48}$ larger than life. This place begets an "agency" 49 of its own and has a "spell" over its visitors as they see its embracing mountains from afar (Ps 121:1-2), the 'earthly link with Yahweh,' the 'touchstone' of God's purposes for them ${ }^{50}$ and the centre of their society. ${ }^{51}$

Moving on from the collective "Person" ideologies to physical "Place," two things are implied, namely sociality and type of place. The communal character of the ma 'a $l o t$-collection has been touched on already, to be is to belong and the individual can hardly exist separated from the group (e.g. Pss 122; 133; 134). The well-being (or distress) of the "I" almost by default becomes extended to the "we" (e.g. Pss 123; 130; 131). This will also be demonstrated in Ps 128 below. In terms of type of place, Zion/Jerusalem fits the "environmental" description (house, neighbourhood [small town], park), the most favourite place that people are attracted to, where locomotion is easy and safe. The larger than life depiction of Zion/Jerusalem, because of its cultural-religious meanings, might create the impression of a very large city and therefore "geographical" place. However, compared to the mega-cities of today, Jerusalem was a small and intimate town.

Before highlighting the thirteen psychological benefits of place attachment ("Process") embedded in Ps 128, a few introductory comments on

46 Levin, "The Edition of the Psalms of Ascents," 400.

47 Levin, "The Edition of the Psalms of Ascents," 400.

48 "'Zion' and 'Jerusalem' are synonyms for the city at the heart of the nation's life..." - Robert Davidson, The Vitality of Worship: A Commentary on the Book of Psalms (Grand Rapids, MI: Eerdmans, 1998), 421.

49 See for instance the personification of Jerusalem in Ps 122, which is a feminine image in the Bible - Schaefer, Psalms, 308-309. See also the vocative "O Jerusalem" in v. 2; On Ps 122 James L. Mays, Psalms, Interpretation (Louisville, KY: John Knox Press, 1994), 393, remarks: "They are to ask after the peace of Jerusalem (v. 6a) as if Jerusalem were a person being greeted by each pilgrim..."

50 Allen, Psalms 101-150, 185, 190.

51 John Eaton, The Psalms: A Historical and Spiritual Commentary with an Introduction and New Translation (London: Continuum, 2005), 437. 
the specific psalm are needed. Psalm 128 is a wisdom psalm, with typical wisdom characteristics such as the "beatitude" (macarism; 'ašrê, v. 1), the "fear" of the Lord (vv. 1, 4; see also e.g. Prov 1:7; Job 28:28) and the "walking in the ways of the Lord" (v. 1, [post-exilic] wisdom of following the Torah) ${ }^{52}$ that clearly indicate the doctrine of retribution. There are also (wisdom typical) similes (v. 3) and the particle hinneh (v. 4) with an instructional function and so also the whole psalm intended as a didactic wisdom psalm. ${ }^{53}$ Psalm 128 forms a "twin" with its immediate predecessor, the wisdom Ps 127, although the wisdom portrayed there is of the protest kind. Apart from an overlap of themes, the two psalms also exhibit a neat chiastic structure in their linking, emphasizing these themes: 127:1 House and city (A), 127:3-4 Blessing of (large) household (B), 127:5 Happy ('ašrê)...(C); 128:1-2 Happy ('ašrê)...(C1), 128:3 Blessing of (large) household (B1), 128:5-6 City and house (-hold) (A1) ${ }^{54} \mathrm{Human}^{55}$ also emphasizes that Ps 128 is fully part of the Psalter (not only Book V), resembling Pss 1:1, 6; 112:1 and 119:1-3 with their emphasis on Torah-ethics (see e.g. Ex 23:25-26; Deut 28:41; Lev 26:14-16). ${ }^{56}$ Ps 128 goes straight to the point with its first words introducing stanza 1 (vv. 1-4), "Happy is everyone who fears (acknowledges) Yahweh..." and neatly encapsulates through inclusio ${ }^{57}$ the first stanza's didactic truth in v. 4, "Look, so is blessed every $\operatorname{man}^{58}$ who fears Yahweh." The enjoying of the fruit of labour, a fruitful wife and many children in between, concretizes this happiness/blessing. Verse 4 not only concludes, but also introduces (functioning as a "hinge" through brk) stanza 2 (vf. 5-6): "May the Lord bless you from Zion..." ${ }^{59}$ Stanza 2 functions as a supplication, wish or

52 Human, "From Exile to Zion," 78.

53 See Human, "From Exile to Zion," 75 and Arthur Weiser, The Psalms: A Commentary (OTL; London: SCM, 1962), 67. Richard J. Clifford, Psalms 73-150 (AOTC; Nashville, TN: Abingdon Press, 2003), 242, however, opts for a "declaration" instead of an "instruction" but misses the thrust of the first stanza.

54 Hendrik Viviers, 'n Teksimmanente ondersoek na die samehang van die ma a $l o t$ psalms (Pss. 120-134), (DD-proefskrif, Universiteit van Pretoria, 1990), 111-112.

55 Human, "From Exile to Zion," 77-79. He also indicates that in Ps 112, other than in Ps 128, the Torah-lifestyle is spelled out in detail.

56 Levin, "The Edition of the Psalms of Ascents," 400, speaks of an editorial "righteousness revision" in Ps 128:1, 4; 130:3-4; 125:3-5a and 129:4, where Godfearing, forgiveness, wickedness and righteousness feature.

57 An inclusio (and closure) also extends over the whole psalm to bind the beginning and end together - see Allen, Psalms 101-150, 184; Viviers, 'n Teksimmanente ondersoek, 109, 111.

58 On the patriarchal bias of the psalm, Schaefer, Psalms, 308, says: "In the Hebrew culture family relations were viewed primarily through the optic of the male figure;" see also Frank-Lothar Hossfeld and Erich Zenger, Psalms 3: A Commentary on Psalms 101-150 (Hermeneia; Minneapolis, MN: Fortress, 2011), 397, 401.

59 Human, "From Exile to Zion," 77, indicates that this blessing could be either profane (said by the host of the house) or priestly (e.g. by a priest at the $\breve{S} u k k o t$ festival, or even a Korahite Levite). 
promise of blessing. ${ }^{60}$ The concretization of this blessing is the prosperity of Jerusalem, grandchildren and peace upon Israel (vv. 5-6). The well-being of the small household "spills over" 61 to include the larger community "household" of Jerusalem and Israel, confirming the psalm's ANE societal values. All of this does not happen in a vacuum but from the "font" 62 of blessing, Yahweh in Zion/Jerusalem (v. 5).

Memory, the psychological benefit of place attachment mostly mentioned and appreciated, is not that upfront in Ps 128, but it is there. The confident instruction (v. 1; 'ašrê in prominent opening position) of the wisdom way of life reaches far back in Israelite history, where this kind of ethos proved to be successful time and again. The past also holds true for the present and future in the post-exilic situation where this ethos, now also combined with Torah-insights (likewise harking back into past history), promises prosperity. And similarly, the special place Zion/Jerusalem, evoking the consoling, collective memory of Yahweh's residence, from where he blesses abundantly (see Ps 133) upholding the "...stream of life..." 63 Building on the old, the poet is also creating a new history, new memories, with the hopeful wish of the continued well-being $(t b)$ of Jerusalem and progeny (vv. 5-6), "especially sons... symbols of the future,"64 and an Israel of peace. ${ }^{65}$ Past and future memories of well-being mark this centre of the world, the "earthly link" that the deity chose to be present in and provide life from. ${ }^{66}$

What does Zion/Jerusalem and surrounds offer in terms of belonging? The "rootedness" of this (Jerusalemite) wise, Torah practising main character has been touched on already, giving him and his family their identity. His "at homeness" becomes aptly expressed in the domestic scene in vv. 2-3. He is wellsettled, making a living probably as a small "farmer," 67 as part of the "ordinary people" ${ }^{68}$ in the $m a^{\text {"a }}$ lot $t$-collection, and able to enjoy ${ }^{69}$ the fruits of his labour. The conspicuous second person suffixes ("your wife..." in "your house", "your

60 Human, "From Exile to Zion," 77. Hossfeld and Zenger, Psalms 3, 397, say that jbrkk in v. 5 "... should be translated as jussive..."

61 Clifford, Psalms 73-150, 243.

62 Clifford, Psalms 73-150, 242.

63 Davidson, The Vitality of Worship, 421.

64 Human, "From Exile to Zion," 73. Allen, Psalms 101-150, 186, adds: “...an

unbroken human chain, generation after generation."

$65 \check{s} l m$ and $t b$ function as synonyms - Hossfeld and Zenger, Psalms 3, 403.

66 Allen, Psalms 101-150, 185.

67 Eaton, The Psalms, 437.

68 Hossfeld and Zenger, Psalms 3, 400.

69 The $k \hat{\imath}$ particle before $t$ ' $k l$ has an emphatic (deictic) function, the man will "surely eat..." - Allen, Psalms 101-150, 182; Hossfeld and Zenger, Psalms 3, 396. 
sons..." around "your table") function as "specification,"70 to mark the ownership of this setting (as family turf, "territory") where he can live a fulfilled life. And the parallel "seeing the prosperity of Jerusalem..." (v. 5) and "seeing your grandchildren..." (v. 6), expands "at homeness" also to the larger community. Mays ${ }^{71}$ summarizes aptly: "Their lives are bound into Zion (emphasis HV), and their hope for blessing is bound up with the good of Jerusalem..."

Relaxation (restoration) and positive emotions (happiness, joy, hope, pride) go hand in hand, the last enhancing the first. The intimate domestic scene of this small farmer after a hard day's manual labour, enjoying the consoling company of his family over a meal, ${ }^{72}$ is replenishing. The repetitive words ' 'sry ("happy"), brk ("blessed") and $t b$ ("prosperous") create an atmosphere of happiness and joy throughout the psalm. The two agricultural similes of the wife as a fertile vine and the sons/children as a flourishing olive tree (vv. 2-3), ${ }^{73}$ speak of "...delight...unspoilt joy in life and vitality..."74 The wife in the innermost parts of the house (běyarkěte beytêk $\bar{a}$ ) has a sexual connotation, ${ }^{75}$ contributing to this man's happiness. Although not stated explicitly, Zion as the wondrous "mediating" source of Yahweh's presence and blessing (v. 5) conveys fascination and awe (see Pss 121:1; 132:13-14; 133; 134:3). Looking forward in the second stanza, the poet also creates hope for the future, adding to happiness also pride; after a long life, to "see" 76 the prosperity of Jerusalem and the peace of Israel and experience the pride of a grandparent of grandchildren. These are obviously the progeny of a fruitful (pōrîyyâ) wife and abundant children (kištile zêtîm - "like the saplings of olive trees"), that filled every ANE man with pride.

70 Rick Marrs, The šyry-hm 'lwt (Psalms 120-134): A Philological and Stylistic Analysis (PhD thesis, The Johns Hopkins University, Baltimore, MD, 1982), 192; Johan A. Burger, Die Chokmatiese Psalms (DTh proefskrif, Unisa, Pretoria, 1985), 95; Daniel Grossberg, Centripetal and Centrifugal Structures in Biblical Poetry (SBLMS 39; Atlanta, GA: Scholars Press, 1989), 42.

71 Mays, Psalms, 403.

72 Hossfeld and Zenger, Psalms 3, 401, indicate that "eat" is associated with joy and prosperity (Deut 12:7; Eccl 9:7). Moreover, in light of this contribution that materiality mediates spirituality, Weiser, The Psalms, 768, says insightfully: "...the fruit of his labour links him spiritually with God's care for him..." The same applies to "place" in general.

73 "The botanical similes fill out the promise with emotive content" - Allen, Psalms 101-150, 185.

74 Weiser, The Psalms, 768; see also Human, "From Exile to Zion," 78.

75 Grossberg, Centripetal and Centrifugal, 44; Hossfeld and Zenger, Psalms 3, 401; Human, "From Exile to Zion," 78; Beat Weber, Werkbuch Psalmen II: Die Psalmen 73 bis 150 (Stuttgart: Kohlhammer, 2003), 303.

76 "the idiom $r^{e} \bar{e} h b^{e}$ means 'to enjoy' (see also Ps cvi 5)" - Mitchell Dahood, Psalms III, 101-150 (AncB 17A; New York, NY: Doubleday, 1970), 229. 
Of the benefits that activities and comfort and security include, Scannel and Gifford name work for a living, interests and physical comfort (food) and safety (safe place). In an ancient world of rather harsh living conditions (droughts, pests, enemies, taxes, etc.) asking for innovative actions, Ps 128 speaks of success. This (happy) man has succeeded in finding "job security" or social security (v. 2) (77 $^{7}$ of which the food he and his family enjoy is tangible evidence. This is obviously also the result of his wise living, "fearing Yahweh" and "walking in his ways" (v. 1). ${ }^{78}$ It is also not only a physical house that provides physical shelter and protection; moreover a caring family does the same. If Ps 128 does not state this explicitly, its "twin" Ps 127:3-5 does. Sons provide a safety net to give him the upper hand over his enemies, and in the ANE protect his highly valued honour. ${ }^{79}$ And Zion/Jerusalem is both the unmistakable symbol of social capital and of protection and safety (e.g. Pss 122; 125), a sanctuary/haven in whose proximity every "insider" Israelite/Jew desires to reside. ${ }^{80}$

In terms of personal growth, what insight and self-reflection opportunities does the small household of Ps 128 offer? The didactic stanza 1 (vv. 1-4), with its framing main theme, the happy wise (God fearing) person living the welltried commandments of old, is what needs to be contemplated on. If there is any doubt about the successful outcome, this is illustrated "materially" with a fulfilled family and community life in Zion/Jerusalem. The (almost) guaranteed retribution of such a life ethos, also allows dreaming of or hoping for a future that looks likewise. It might be a "simple philosophy" 81 but it works. As part and parcel of the whole Psalter, Ps 128 becomes fully part also of its "meditative pilgrimage," taking stock of Israel's troubled but also history of salvation and to proceed confidently towards the future.

The practical possibilities and freedom that a specific place offers, can perhaps be put together, namely the possibilities to live and work meaningfully and the freedom to exercise autonomy to achieve a successful/satisfied life through the place's potential. A Judaean "farmer" carving out a living in the hill country around Jerusalem was far more challenged than those that lived on the fertile plains. The archaeological record has highlighted some of these innovative measures (building terraces, harvesting of water, mixed farming, family labour force, etc.), testifying of the (then) farmers' creativity, and not essentially differing from that of modern farmers. "Work done not only provides for daily

77 Hossfeld and Zenger, Psalms 3, 401.

78 The synthetic parallelism clearly specifies what it means to live in recognition of Yahweh.

79 Human, "From Exile to Zion," 73.

80 Levin, "The Edition of the Psalms of Ascents," 400.

81 Allen, Psalms 101-150, 186. 
physical needs, but brings with it contentment and satisfaction...," 82 and confirming the positive emotions mentioned above associated with rewarding labour. The solving of (survival) problems has been part of our humanness since the early dawn of humankind and always highly gratifying. Furthermore, the proximity of the prosperous city of Jerusalem offers all the amenities such a farmer needs, for instance trading and selling surplus goods.

Psalm 128 also reflects the remaining benefits of place attachment. The intimate domestic scene of the family household (vv. 2-3) speaks of privacy, escaping the glaring/censuring eyes of the neighbours, all humped together in these tight-knit communities, notably also when it comes to matters sexual. Enjoying a satisfying meal together whilst sharing the daily happenings speaks of entertainment. This also offers the opportunity to revisit and re-enact the master (and minor) shaping narratives of the Israelite politico-socio-cultural history in the inner circle, but also equipping family members to partake in the matching festivals in the broader community in an informed way. Jerusalem is also the vibrant, attractively built city with numerous impressive structures ("House of the Lord," gates, thrones of judgement, walls, citadels - Ps 122) that captures the attention and satisfies the human need for stimulation and excitement. Many respondents partaking in the study of Scannel and Gifford ${ }^{83}$ reported a connection to nature whilst in a special place. Ancient Israel might not share our modern (romantic) appreciation of (especially wild) nature ${ }^{84}$ but for a people living from and close to nature as agriculturalists, the bounty of nature was celebrated (see again the botanical similes of vv. 2-3; see also Pss $126: 4-6 ; 132: 15 ; 133)$. And similarly aesthetics, of people resembling nature's pleasant beauty and vitality. Looking also at a thriving, lively city (Jerusalem, v. 5) built on mountainous terrain (Ps 125:1-2), with the temple hill (Zion) as a special marker, was an aesthetic experience. It captured the eye of admiring visitors and inhabitants alike.

A last comment also on the positive behaviour of inhabitants towards their place of attachment, that Scannel and Gifford mentioned above. Wise Torah-abiding living (vv. 1, 4), the main theme of Ps 128 , is in the eyes of the poet the best thing that someone can do to upkeep and preserve the household. The prosperity and longevity (vv. 2-3) that this guarantees for the house has a ripple effect on the future "good" $(t b)$ also for the wider community of Jerusalem. The explicit wish/supplication for the well-being (vv. 5-6) of Jerusalem and Israel confirms the desire that this special place should stay intact.

\footnotetext{
82 Davidson, The Vitality of Worship, 420.

83 Scannel and Gifford, "The Experienced Psychological Benefits," 262.

84 Exceptions are eco-centric ("green") texts like the Song of Songs, Ps 104 and Job to name but a few, appreciating nature in its own right.
} 


\section{CONCLUSION}

Place attachment extends far back into human history, where humans have occupied "territories" to physically survive but soon learned to confer emotional and spiritual meanings on place, to also claim ownership of it in this way. As much as people "shape" their surrounds, the last-mentioned in turn do likewise to their inhabitants. A material place, therefore, "matters" as it mediates these ascribed, transcended meanings through its sensuous presence. The ancient creators of the ma "a $l o t$-collection and Ps 128 specifically (also as part of the whole Psalter) have intuitively grasped and verbalized the cognitive-emotional bond, described by modern psychology, that humans forge with a place. In Ps 128 the ordinary, intimate household illustrates the place attachment experiences of memories, belonging, happiness and pride, comfort and security, beauty, privacy, entertainment and reflection on its main theme, the tried and trusted wisdom-Torah ethical lifestyle for a successful life. The household is socially also part of the bigger household Zion/Jerusalem (and Promised Land Israel), Yahweh's "powerhouse" from where he blesses abundantly. The future wellbeing of this special place is also dreamed of, to still mediate the ultimate, cosmological meanings that its inhabitants have come to associate with their "larger than life" centre of the world.

Reading Ps 128 through the "lens" of place attachment does not only confirm its age-old truths, but testifies to our shared human experience of the importance of place bonds.

\section{BIBLIOGRAPHY}

Allen, Leslie C. Psalms 10--150. WBC 21. Waco, TX: Word, 1983.

Burger, Johan A. Die Chokmatiese Psalms. Pretoria: DTh proefskrif Unisa, 1985.

Chidester, David. Religion: Material Dynamics. Oakland, CA: University of California Press, 2018. https://doi.org/10.1525/california/9780520297654.001.0001.

Clifford, Richard J. Psalms 73-150. Abingdon Old Testament Commentaries. Nashville, TN: Abingdon, 2003.

Dahood, Mitchell Psalms III: 101-150. The Anchor Bible 17A. New York, NY: Doubleday, 1970.

Davidson, Robert. The Vitality of Worship: A Commentary on the Book of Psalms. Grand Rapids, MI: Eerdmans, 1998.

Eaton, John. The Psalms: A Historical and Spiritual Commentary with an Introduction and New Translation. London: Continuum, 2005.

Grossberg, Daniel. Centripetal and Centrifugal Structures in Biblical Poetry. Society of Biblical Literature: Monograph Series 39. Atlanta, GA: Scholars Press, 1989.

Holtzhausen, Herman. "Ubuntu, Mysticism and Land Reform: A Spiritual Response to the Debate on the Expropriation of Land without Compensation." Unpublished summary article of PhD, University of Pretoria, Pretoria, 2019: 1-22.

Hossfeld, Frank-Lothar and Zenger, Erich. Psalms 3: A Commentary on Psalms 101150. Hermeneia. Minneapolis, MN: Fortress, 2011. 
Human, Dirk J. "“From Exile to Zion' - Ethical Perspectives from the Twin Psalms 127 and 128." Old Testament Essays 22 (2009): 63-87.

Jordaan, Wilhelm. "Ruimtekapers, dít is nié goeie maniere nie." Beeld (13 Februarie 2019): 10.

Kaplan, Stephen. "The Restorative Benefits of Nature: Toward an Integrative Framework." Journal of Environmental Psychology 15 (1995): 169-182. https:// doi.org/10.1016/0272-4944(95)90001-2.

Levin, Christoph. "The Edition of the Psalms of Ascents." Pages 381-400 in Centres and Peripheries in the Early Second Temple Period. Edited by Ehud Ben Zvi and Christoph Levin. Tübingen: Mohr Siebeck, 2016. https://doi.org/10.1628/978-316-155025-6

Lewicka, Maria. "Place Attachment: How Far have we come in the last 40 years?" Journal of Environmental Psychology 31 (2011): 207-230. https://doi.org/10 .1016/j.jenvp.2010.10.001.

Marrs, Rick. The šyry-hm 'lwt (Psalms 120-134): A Philological and Stylistic Analysis. $\mathrm{PhD}$ thesis, The Johns Hopkins University, Baltimore, MD, 1982.

Mays, James L. Psalms. Interpretation. Louisville; KY: John Knox Press, 1994.

Meyer, Birgit. "An Author meets her Critics: Around Birgit Meyer's 'Mediation and the Genesis of Presence: Toward a Material Approach to Religion." Religion and Society: Advances in Research 5 (2014): 205-254. https://doi.org/10.3167/ arrs.2014.050114.

Prinsloo, Gert T. M. "The Role of Space in the שירי המעלות (Psalms 120-134)." Biblica 86 (2005): 457-477.

Quin, Courtney E. and Halfacre, Angela C. "Place Matters: An Investigation of Farmers' Attachment to Their Land." Human Ecology Review 20 (2014): 117132. https://doi.org/10.22459/HER.20.02.2014.06.

Scannel, Leila and Gifford, Robert. "Defining Place Attachment: A Tripartite Organizing Framework." Journal of Environmental Psychology 30 (2010): 1-10. https://doi.org/10.1016/j.jenvp.2009.09.006.

Scannel, Leila and Gifford, Robert. "The Psychology of Place Attachment." Pages $273-$ 300 in Environmental Psychology, $5^{\text {th }}$ ed. Edited by Robert Gifford. Colville, WA: Optimal Books, 2013. Available online at: https://www.researchgate.net/publication/279718543_The_psychology_of_plac e attachment

Scannel, Leila and Gifford, Robert. "The Experienced Psychological Benefits of Place Attachment." Journal of Environmental Psychology 51 (2017): 256-269. https:// doi.org/10.1016/j.jenvp.2017.04.001.

Schaefer, Konrad. Psalms. Berit Olam. Collegeville, MN: Liturgical Press, 2001.

Seybold, Klaus. "Die Redaktion der Wallfahrtspsalmen." Zeitschrift für die alttestamentliche Wissenschaft 91 (1979): 247-268. https://doi.org/10.1515 lzatw.1979.91.2.247

Stedman, Richard. "Is it really just a Social Construction? The Contribution of the Physical Environment to Sense of Place." Society and Natural Resources 16 (2003): 671-685. https://doi.org/10.1080/08941920309189.

Van der Ploeg, Johannes P. M. Psalmen, deel 1. BOT 7B. Roermond: J Romen, 1974.

Viviers, Hendrik. 'n Teksimmanente ondersoek na die samehang van die ma 'a ${ }^{\text {lott-psalms }}$ (Pss. 120-134). DD-proefskrif, Universiteit van Pretoria, Pretoria, 1990. 
Viviers, "Psychology of Place Attachment," OTE 32/2 (2019): 426-443 443

Viviers, Hendrik. "The Coherence of the ma al lôt Psalms (Pss 120-134)." ZAW 106 (1994): 275-289. https://doi.org/10.1515/zatw.1994.106.2.275.

Weber, Beat. Werkbuch Psalmen II: Die Psalmen 73 bis 150. Stuttgart: Kohlhammer, 2003.

Weiser, Arthur. The Psalms: A Commentary. Old Testament Library. London: SCM, 1962.

Prof Hendrik Viviers, Department of Religion Studies, University of Johannesburg, South Africa, hviviers@uj.ac.za. ORCID: https://orcid.org/00000003-4194-2988. 